\title{
The impact of the crisis and austerity on low educated working women: the cases of Spain and Portugal
}

DOI:

10.1111/gwao.12238

\section{Document Version}

Accepted author manuscript

Link to publication record in Manchester Research Explorer

\section{Citation for published version (APA):}

Tavora, I., \& Rodríguez-Modroño, P. (2018). The impact of the crisis and austerity on low educated working women: the cases of Spain and Portugal. Gender, Work and Organization, 25(6), 621-636.

https://doi.org/10.1111/gwao.12238

\section{Published in:}

Gender, Work and Organization

\section{Citing this paper}

Please note that where the full-text provided on Manchester Research Explorer is the Author Accepted Manuscript or Proof version this may differ from the final Published version. If citing, it is advised that you check and use the publisher's definitive version.

\section{General rights}

Copyright and moral rights for the publications made accessible in the Research Explorer are retained by the authors and/or other copyright owners and it is a condition of accessing publications that users recognise and abide by the legal requirements associated with these rights.

\section{Takedown policy}

If you believe that this document breaches copyright please refer to the University of Manchester's Takedown Procedures [http://man.ac.uk/04Y6Bo] or contact uml.scholarlycommunications@manchester.ac.uk providing relevant details, so we can investigate your claim.

\section{OPEN ACCESS}




\title{
The impact of the crisis and austerity on low educated working women: the cases of Spain and Portugal $^{1}$
}

\author{
Isabel Távora ${ }^{2}$ \\ University of Manchester, UK \\ Paula Rodríguez-Modroño \\ Pablo de Olavide University, Seville, Spain
}

\begin{abstract}
This article investigates the impact of the recent economic crisis and associated austerity agenda on working low educated women in Portugal and Spain. It draws firstly on a comparative analysis of Eurostat LFS data, recent reform to labor market and care policy; secondly, on qualitative research exploring changes in low educated women's employment, family arrangements and values.

The findings reveal that in both countries low educated women maintained their labor market attachment but faced increased risks of labor market exclusion, precarity and low pay. However, the weight of women's household income contributions increased in the context of male unemployment and earnings insecurity, which reinforced women's work attachment. Moreover, employment appeared critical to women's identity and associated with egalitarian values. Despite greater protection of equality policies and welfare support for dual-earner families in Portugal, the evidence suggests a negative impact of austerity on work-family reconciliation opportunities for low educated women in both countries.
\end{abstract}

Keywords: Female employment, low educated women, gender equality, crisis.

\section{Introduction}

Low educated women are more vulnerable to unemployment, employment insecurity, and low pay than better educated women who tend to have better access to employment and higher individual bargaining power in the employment relationship. For that reason, employment and income institutional protections are particularly important to secure decent work and living standards for this group of women (Mandel and Shalev, 2009). Likewise, welfare policies that support female employment such as publicly-funded childcare have a greater impact on enabling labor market

\footnotetext{
${ }^{1}$ This is an earlier version of an article accepted for publication in Gender, Work and Organization

${ }^{2}$ Corresponding author: Isabel Távora, Alliance Manchester Business School, Booth Street East, Manchester M13 9SS, UK.

Email: Isabel.tavora@manchester.ac.uk
} 
participation of mothers with lower levels of education than of those with higher education (Korpi $e t$ al., 2013). Due to their higher earnings potential and ability to pay for market-based childcare, the latter tend to have high rates of participation irrespective of public policy arrangements but free or low cost childcare are crucial for making work pay of lower educated women (Hook, 2015).

An emerging body of research about the impact of the recession and austerity on women recognized but did not examine in depth the potential different impact of the crisis and austerity reforms on different groups of women, particularly how it affected the labor market access, employment attachment, and experience of low educated women (e.g. Bettio et al., 2013; Antonopoulos, 2014; Karamessini and Rubery, 2014; Leschke and Jepsen, 2014; Walby, 2015; Bargawi et al., 2017; Kantola and Lombardo, 2017). Yet this is an important question. The policy responses to the crisis at the European and national level consisted mostly of measures to cut public spending and to increase labor market flexibility, targeting welfare programs, public sector employment and pay, employment protection legislation, and wage setting institutions (Távora and González, 2016). While the cuts to public sector pay and employment are likely to affect professional women at least as much as women with medium and lower levels of education, the latter are more likely to be negatively affected by reforms that reduce protection against low pay, restrict employment rights and reduce funding for care and support for working parents. Previous research has focused mostly on how austerity affected welfare support for women but less so on the gender impact of the labor market measures.

This article aims to address some of these gaps through an intersectional focus on low educated women in order to contribute to a better understanding of how the crisis, austerity and employment deregulation affected the patterns, conditions, and experience of this particularly disadvantaged group of women ${ }^{1}$. It does so by focusing on two of the European Union countries with higher shares of low educated workers, that were most affected by the crisis, and where austerity policy responses have been most severe: Portugal and Spain. The next section explains the analytical framework used in the analysis, the research context and the specific research questions, followed by an explanation of the methods used to address them. The findings are then presented followed by a discussion of their implications.

\section{Understanding female employment during the recession in Portugal and Spain}

The framework for the analysis in this paper is based on Rubery's $(1988,2014)$ theorizing on women and recession and Pfau-Effinger's (1998) approach to how gender relations and women's employment change over time. In these perspectives, change to gender relations needs to be understood in the historical and cultural context of women's employment integration. The extent to which women are affected by a recession and austerity-driven reforms depends on the robustness of normative and state support for female employment and how those reforms affect and interact with societal institutions, norms, and values. The focus on low educated women is underpinned by an intersectionality-sensitive 
approach (McBride et al,, 2015) that recognizes that processes shaping gender inequalities vary and may lead to different outcomes for different categories of women. Thus the intersection of gender and low education may exacerbate vulnerability to crisis-related institutional and labour market change to varying extents and in different ways in different national contexts.

Despite their similar cultural heritage, women's employment position and the gender arrangements are rather different in the two countries. In Spain, women's labor market participation has grown more gradually and more recently than in Portugal, where historical labor shortages caused by the colonial wars and emigration in the 1960-70s triggered the growth of women's employment. This led to Portuguese women gaining an early foothold in the core labor market. Their pattern of employment is mostly full-time and continuous, even among low educated women (Távora, 2012). This contrasts with the path of Spanish women, who have entered employment mostly through the peripheral segments of the labor market. Care-related breaks are still relatively common among Spanish women, who are also more likely to be entrapped in temporary forms of employment and, increasingly, in part-time work, which in Spain tends to be involuntary and highly precarious (González-Gago and Segales, 2014; Muñoz-de-Bustillo and Pinto Hernández, 2016). The modernization of family values in both countries, particularly among the younger cohorts, underpins new and more diverse household arrangements (Moreno and Marí-Klose, 2013; Naldini and Jurado, 2013). However, while in Portugal dual breadwinner families in which both partners work full-time have become the norm, in Spain male breadwinner families and modified versions have remained important. In 2008, seventy three percent of Portuguese families with children were dual earner families but this percentage was approximately fifty four percent in Spain and, while the percentage of dual earner families in which one of the parents worked part-time in Portugal was just seven percent, this proportion in Spain was seventeen percent (Escobedo and Wall, 2015). Despite these differences, there had been significant convergence between the countries in the period that preceded the crisis. Eurostat data show that while in 1992 the female employment rate in Spain was thirty two percent (compared to fifty six in Portugal), in 2007 it had grown to fifty five percent (compared to sixty two percent in Portugal). However, this convergence was less pronounced among low educated women, whose employment rates grew in the same period from twenty seven to forty two percent in Spain and from fifty two to fifty seven percent in Portugal (Eurostat, 2017).

The relevance of the different profiles with which the two countries met the crisis is that they help us consider how Portuguese and Spanish women may have been differently affected by the crisis and the austerity reforms. Where the pre-crisis attachment to employment is lower, women's employment position may be more fragile (Rubery, 2014). 'Added worker effects', of women increasing their labor market participation in response to male unemployment, were noticeable in Spain during the crisis (Bettio and Verashchagina, 2014; Addabbo et al, 2015, Gálvez and Rodríguez-Modroño 2016). However, the likelihood of these 'added' women workers withdrawing from the labor market when the circumstances change again depends on how far their employment integration has become 
associated with changes in the household economy, gender roles, and social norms (Rubery, 2014). These changes may be difficult to reverse but less so where women's employment attachment is less robust, or more recent. Following this logic, the employment position of women, especially the low educated, may be more vulnerable to recession and austerity in Spain compared to Portugal.

Moreover, examining how supportive policies, such as care services and leaves for parents, evolved before and during the crisis is another important dimension for analyzing the impact of the crisis on women, especially low educated women, who benefit the most from them (Keck and Saraceno, 2012, Korpi et al., 2013). Where dual earner families have become the norm, like in Portugal, state support is more likely to be sustained. Where male breadwinner arrangements remain significant, as in Spain, austerity may present a greater threat to these policies.

The aim of this article is to improve understanding of changes in gender relations and the employment position of low educated women in employment under recession and austerity. The research focus on these two Southern European countries is justified firstly by these being among the European Union member states most affected by the crisis and where austerity policies have been harsher. Secondly, with relatively high shares of low educated workers in the active population nearly fifty percent in Portugal and forty percent in Spain (Eurostat, 2017), these countries provide particularly interesting contexts in which to investigate how austerity and labor market deregulation have affected low educated women.. Thirdly, the two countries vary in the levels and history of female employment and in the prevalence of dual earner households. This allows us to examine whether female employment attachment and supportive policies are, as expected, more fragile where this attachment is lower, less normative, and more recent.

In particular, we compare the two countries in relation to the following questions:

1. To what extent have low educated working women been affected by the crisis and associated labor market reforms in their access to employment? Are the crisis and reforms associated with a worsening of their employment conditions and experience?

2. Have austerity measures affected the equality agenda and welfare support for female employment, particularly care and leave policies? If so, how do these changes affect low educated women's ability to reconcile work with family responsibilities?

3. To what extent are the changes in employment of women and men during the crisis associated with changes in the household economy, family arrangements, and gender roles and attitudes in either of the countries? Have these changes affected the employment attachment of low educated women?

These questions are addressed in two stages that draw on different types of data which combined provide both breadth and depth to the analysis:

- Stage one, in the next section, involves a comparative analysis of Eurostat Labour Force Survey (LFS) data on activity, employment and unemployment followed by a systematic review of crisis-driven labor market reforms and what is already known about their 
employment impact as well as developments in care and leave policies in each country. This will reveal macro-level trends in female labor market participation, including how far crisisdriven reforms increased the risks of labor market exclusion, low pay and/or precarity for low educated women and decreased their opportunities to reconcile working and caring

- Stage two, in the following section, explores these themes further through a qualitative analysis that draws on case-based data from primary research in Portugal and Spain to provide an account of actual experiences of low educated working women. This offers a micro-level illustration of how the patterns identified at the macro-level play out in practice. It reveals how austerity and employment deregulation can affect the experience of work in its interface with the family sphere of low educated women and their gender-role attitudes. The methodological details of the qualitative research are provided in the beginning of the section.

\section{Female employment, labor market and welfare reform under crisis and austerity}

\section{Labor market participation and inclusion}

Previous research of the impact of the recent crisis on women revealed a number of effects that are now well known. First, despite the decline of employment and rise of unemployment, women continued looking for jobs and female labor market participation increased almost everywhere in Europe; secondly, gender differences in employment narrowed due to male-dominated sectors such as construction and manufacturing being the most affected by job losses and to the growth of precarious employment among men (Bettio et al., 2013; Karamessini and Rubery, 2014). Nevertheless, women were also affected by unemployment and job insecurity and there was a halt of the progress towards higher female employment levels and a deterioration of employment standards for both genders (Bettio and Verashchagina, 2014). This sub-section analyzes how these effects played out in Portugal and Spain for low educated women. Drawing on Eurostat LFS data summarized in table 1 (below), it compares trends in labour market participation of low educated women between Portugal and Spain and in relation to other social groups. The table shows that activity rates of low educated women increased in Spain, consistent with overall female activity rates which increased in both countries. However, those of low educated Portuguese women decreased, more in alignment with those of men, which declined in both countries. These trends led to a significant convergence of activity rates between the two countries both for women overall and low educated women. Employment rates dropped markedly for men and even more so for those with lower education. While for women this decline was smaller, it was still quite sharp in the case of Portuguese low educated women, who were the only group whose employment rates continued to decline after 2012. In Spain, the dramatic growth of unemployment was sharper among men but reached higher levels among women, reaching almost thirty five percent for low educated women. The increase of unemployment in Portugal was less pronounced but it also reached unprecedented levels, particularly for low educated women. For this social group, the unemployment rate surpassed twenty five percent in 2012, from a starting point 
of just below eleven percent in 2007 (Table 1). A decline of unemployment became apparent after 2012. However, for low Portuguese educated women this decline of unemployment was not matched by an increase of employment rates, which is indicative of labor market withdrawal of discouraged workers into inactivity.

Table 1. Activity, employment and unemployment rates in Portugal and Spain (\%)

\begin{tabular}{|c|c|c|c|c|c|c|}
\hline & \multicolumn{3}{|c|}{ Portugal } & \multicolumn{3}{|c|}{ Spain } \\
\hline & 2007 & 2012 & 2015 & 2007 & 2012 & 2015 \\
\hline Female activity rates & 68.7 & 69.7 & 70.3 & 61.9 & 68.4 & 69.0 \\
\hline Low educated & 64.4 & 61.0 & 58.8 & 48.8 & 56.5 & 57.2 \\
\hline Male activity rates & 79.2 & 77.3 & 76.7 & 81.4 & 80.1 & 79.5 \\
\hline Low educated & 78.8 & 74.6 & 72.0 & 78.7 & 76.2 & 75.8 \\
\hline Female employment rates & 61.8 & 58.5 & 61.1 & 55.3 & 51.2 & 52.7 \\
\hline Low educated & $\mathbf{5 7 . 5}$ & 50.7 & 50.5 & 41.5 & 37.0 & 37.7 \\
\hline Male employment rates & 73.6 & 64.5 & 66.9 & 76.1 & 60.3 & 62.9 \\
\hline Low educated & 73.1 & 61.2 & 61.6 & 72.4 & 50.7 & 53.7 \\
\hline Female unemployment rates & 10.1 & 16.1 & 13.1 & 10.7 & 25.2 & 23.7 \\
\hline Low educated & 10.6 & 25.5 & 24.4 & 16.9 & 34.6 & 34.2 \\
\hline Male unemployment rates & 7.0 & 16.5 & 12.8 & 6.5 & 24.7 & 20.9 \\
\hline Low educated & 7.2 & 17.8 & 14.3 & 8.0 & 33.4 & 29.2 \\
\hline
\end{tabular}

Source: Eurostat. Note: 'Low educated' corresponds to ISCED levels 0-2 of education attainment: less than primary, primary and lower secondary education.

In sum, the labor market impact of the crisis was particularly severe for the low educated. Spanish women joined the labor market as men lost jobs but faced increasing barriers to securing employment. However, low educated women in both countries met even greater difficulties in accessing, maintaining and re-entering employment.

\section{Labor market reforms and their impact}

The wide-ranging labor market reforms implemented in the two countries during the crisis affected key areas of employment protection including dismissals, working time flexibility, and wage determination (Rocha and Stoleroff, 2014; Fernández-Rodríguez et al., 2016). In Spain, changes to labour law increased firms' discretion to modify workers' tasks, location, and schedules and research suggests that this led to a growth of precarious work and to employers' abusing part-time contracts to reduce costs by replacing full-time workers with lower paid part-timers, and pressuring part-timers to work longer unpaid hours (Rocha, 2014). In Portugal, the legal changes included new working 
time accounts and cutting overtime pay, which limited opportunities for overtime work and/or pay and reduced overall earnings of many workers (Távora, 2016). In both countries, these changes reduced the predictability and workers' control of working hours, with potential negative implications for work-family reconciliation.

Changes to wage determination institutions have also affected workers negatively. In Portugal the minimum wage was frozen between 2011 and 2014 and in Spain in 2012 and 2014 (Cruces et al., 2014). The proportion of workers earning the minimum wage rose sharply in both countries: from five to fifteen percent among men and from twelve to twenty five percent among women in Portugal between 2009 and 2014 (Instituto Nacional de Estatística, 2016); in Spain this increase was from five to eight percent for men and from fourteen to nineteen percent for women between 2008 and 2014 (INE, 2017). The growing proportion of minimum wages earners suggests a lower capacity of collective bargaining to protect workers from low pay. Indeed, while collective bargaining coverage has been high in Portugal (eighty percent) and Spain (seventy three percent) (Visser, 2013), its operation has been severely constrained by the crisis-driven reforms. These led to bargaining blockages which resulted in a sharp decline in the coverage of new agreements, notably in Portugal (Rocha and Stoleroff, 2014; Cruces et al., 2015). In Spain, the reforms created opportunities for firms to opt out from collective agreements and unilaterally reduce wages (Fernández-Rodríguez et al., 2016).

These changes in both countries undermined the effectiveness and protective role of collective bargaining. Taken together, minimum wage freezes and collective bargaining blockages in Portugal resulted in many workers in low wage sectors not receiving wage increases between 2011 and 2014 (Távora and González, 2016). Research in Spain suggests that wage cuts were relatively widespread during the crisis (Fernández-Rodríguez et al., 2016). Average real wages in the 2010-2013 period declined more than six percent in both countries (Cruces et al., 2015). Despite the reforms affecting both men and women, the gender pay gap increased in the 2007-2013 period from eighteen to nineteen percent in Spain and from nine to thirteen percent in Portugal (Eurostat, 2017). This increase is partly explained by public sector wage cuts and by the minimum wage freezes, which affected women disproportionally.

On the positive side, legal rules introduced in Portugal between 2009 and 2012 established that new collective agreements are to be assessed by the Commission for Equality at Work with respect to their conformity with equality legislation (Ferreira and Monteiro, 2013). The signatory parties are required to change dispositions found to be inconsistent with equality legislation, which has already produced positive changes in the content of some collective agreements (Ferreira and Monteiro, 2013). This contrasts with the Spanish case where institutions and government bodies to promote equality were dismantled during the crisis (León and Pavolini, 2014; Lombardo, 2017b). 
Welfare support for women's employment

While Portugal and Spain's welfare state support for women had traditionally been low, this had improved considerably in the decades that preceded the crisis, despite complementary family-based and informal arrangements remaining significant (Távora, 2012). In particular, formal childcare services had significantly expanded in the decade that preceded the crisis. By 2007, just before the crisis, coverage for children under three stood at twenty seven percent in Portugal and thirty nine percent in Spain (Eurostat, 2017; see also table 2) ${ }^{2}$. In both countries, childcare services had become relatively affordable, with fees based on parents' income and, from three years old, pre-school education in Spain is guaranteed free of charge (Távora, 2012; European Commission, 2014; Escobedo et al., 2015). With the advent of austerity, childcare expansion programs in Portugal were temporarily suspended in 2011, but growth in coverage was sustained partly due to falling fertility rates and new rules allowing more children per classroom (Escobedo and Wall, 2015). In Spain, budgetary cuts to public childcare funding affected mainly services for children under three, though restriction to supplementary services such after school care affected also older children (Ibáñez and León, 2014; Rodríguez-Modroño and Matus, 2016). Table 2 below displays data on formal childcare services. It shows that in Portugal, where childcare coverage was lower than in Spain in 2007, coverage continued to grow steadily throughout the crisis period whereas in Spain there was a slight decline for children under three. The countries differ also in hours children spend in care (Table 2). Consistent with the higher rates and prevalence of dual breadwinner families in Portugal, formal childcare tends to be used and provided on a full-time basis in Portugal but on a part-time basis in Spain. Despite regional variations (León, 2007; Baizán, 2009), the fact that childcare is often not available on schedules compatible with full-time working continues to constrain dual earner family arrangements in Spain.

Table 2. Children below minimum compulsory school age in formal childcare $(\%)$ and average hours* spent in care in Portugal and Spain, 2007 and 2014

\begin{tabular}{|c|c|c|c|c|c|c|c|c|}
\hline & \multicolumn{4}{|c|}{ Portugal } & \multicolumn{4}{c|}{ Spain } \\
\hline & \multicolumn{2}{|c|}{2007} & \multicolumn{2}{|c|}{2014} & \multicolumn{2}{c|}{2007} & \multicolumn{2}{c|}{2014} \\
\hline & $\%$ & Hours & $\%$ & Hours & $\%$ & Hours & $\%$ & Hours \\
\hline Less than 3 years & 27 & 42.3 & 45 & 37.5 & 39 & 26.5 & 37 & 26.7 \\
\hline 3 years or more & $\mathbf{7 5}$ & $\mathbf{3 6 . 7}$ & $\mathbf{8 9}$ & $\mathbf{3 9 . 7}$ & $\mathbf{9 1}$ & $\mathbf{2 8 . 9}$ & $\mathbf{9 3}$ & $\mathbf{2 9}$ \\
\hline
\end{tabular}

* Average number of weekly care hours of children who spend at least one hour per week in care. Source: Eurostat SILC, online database.

Up to the crisis, leave systems in Portugal and Spain had many similarities but also some differences (Escobedo and Wall, 2015). In both countries fully paid maternity leave was available for sixteen weeks but in Portugal since 2003-4 this could be extended to twenty weeks paid at eighty percent of previous earnings. In both countries maternity leave could be shared with fathers except 
for the six weeks following the birth. There were leave entitlements exclusive for the father: twenty days in Portugal since 1999 but remained only two days in Spain until 2007, when it was extended to fifteen days (Ley 3/2007). The latter was due to be extended to twenty days in 2011 but this was successively postponed until January 2017. Parental leave existed but was unpaid in both countries though from 2000 some Spanish regions had started to offer benefits to support parental leave, but these were mostly withdrawn during the crisis. While in Spain austerity restricted improvements on leave policy, in Portugal there was a major reformulation in 2009:maternity leave was re-labeled into the more egalitarian term 'initial parental leave' which can be extended by a month if shared with the father (to a maximum of six months paid at eighty percent of previous earnings); secondly, a period of additional extended leave of three months paid at twenty five percent replacement rate became available to each parent (Decreto-lei 89/2009). In 2015, father-only leave was further extended by five days (Lei 120/2015).

In both countries, state support for elderly care continues to be more limited than to childcare, still relying heavily on family-based and informal arrangements. The creation of a long-term care program was an important development in Spain just before the crisis but hardly implemented as it was immediately subject to severe budget cuts (Rodríguez-Modroño and Matus, 2016). Under austerity, elderly care services and subsidies were drastically curtailed (Real Decreto-Ley 20/2012). In Portugal, the expansion of social care was temporarily suspended but existing programs were not affected (Ferreira, 2014). Official data shows that elderly care services kept growing, if modestly, between 2010 and 2014 in Portugal (Gabinete de Estratégia e Planeamento, 2014).

\section{Micro-level effects in the experience of low educated women in Portugal and Spain}

While the previous section used cross-national and national data to compare trends in low educated women's labour market participation and developments in welfare and labour market policies and their consequences, here we draw on qualitative research to investigate how these developments might affect the experience of employment of low educated women and the work-family interface. We also wanted to understand whether changes in employment of low educated women and of their male partners and in the household economy were likely to be associated with changes in gender relations and values.

\section{Research methods}

Our qualitative data was gathered through two qualitative studies conducted in 2014 in low wage feminized sectors that employ large numbers of low educated women in Portugal and Spain. In each country the research took place in comparable regions, both characterized by higher levels of unemployment and lower levels of female employment than the national averages ${ }^{3}$ and, despite these differences being more pronounced in Spain, employment opportunities for low educated women in 
local labor markets were relatively limited in both cases. The Portuguese study involved thirty one interviews with women working in clothing manufacturing in the North region. The Spanish study involved fifty three women employed in clothing and agro-food manufacturing (nineteen), retail, accommodation and food services (seventeen), and social care (seventeen) in Andalucía region of southern Spain. The differences between the sectors of employment of Spanish and Portuguese interviewees reflect to a considerable extent differences in the industries in which low educated women tend to work in these countries. In contrast with elsewhere in Europe, the manufacturing industry is an important sector for women in Portugal, where they have a forty percent share of employment and where fourteen percent of female employment is in this industry; in Spain these figures are much lower: women's share of manufacturing employment is twenty six percent and only seven percent of employed women work in manufacturing (Eurostat, 2017). Therefore, even though the Spanish sample may be more representative in portraying the diversity of experiences of low educated women working in a range of sectors, the interviewees in both country-studies are quite typical in terms of the industries in which low educated women tend to work in both Portugal and Spain. Moreover, in both countries the women interviewed were similarly employed in low skilled jobs, and the vast majority had attained only lower secondary education or less (with two exceptions in Portugal and eight in Spain of women who had completed secondary education). Their average age was thirty eight in Portugal, and forty three in Spain. The interviewees in both countries typically had either one or two children, with only two cases of women in each country with three children. In most cases, the interviewees who were mothers of minor children lived with their husbands or partners with only three cases of single parenthood in Spain and two in Portugal. Twenty three interviewees in Portugal and twenty two in Spain had minor children and of these, thirteen in Portugal and eight in Spain had pre-school children. Table 3 displays a summary of the characteristics of the samples in the two countries. 
Table 3. Main characteristics of the samples in Portugal and Spain

\begin{tabular}{|c|c|c|}
\hline & Portugal & Spain \\
\hline $\begin{array}{l}\text { Total number of } \\
\text { interviewees }\end{array}$ & 31 & 53 \\
\hline $\begin{array}{l}\text { Industry, job } \\
\text { features and } \\
\text { geographical } \\
\text { setting }\end{array}$ & $\begin{array}{l}\text { Low skilled/low wage jobs in } \\
\text { clothing manufacturing } \\
\text { Evenly distributed by urban, semi- } \\
\text { urban and rural settings in the } \\
\text { North region }\end{array}$ & $\begin{array}{l}\text { Low skilled/low wage jobs in agro- } \\
\text { food and clothing manufacturing } \\
\text { (19); retail, accommodation and } \\
\text { catering (17), and social care (17) } \\
\text { Evenly distributed by urban, semi- } \\
\text { urban and rural settings in the } \\
\text { South region }\end{array}$ \\
\hline Education level & $\begin{array}{l}\text { Lower secondary or less (29) } \\
\text { Upper secondary education (2) }\end{array}$ & $\begin{array}{l}\text { Lower secondary or less (45) } \\
\text { Upper secondary education (8) }\end{array}$ \\
\hline Age & From 24 to 53. Average age: 38 & From 24 to 62 . Average age: 43 \\
\hline $\begin{array}{l}\text { Family } \\
\text { circumstances }\end{array}$ & $\begin{array}{l}23 \text { women had minor children } \\
13 \text { had pre-school children aged } \\
\text { from below } 1 \text { to } 5 \text { years } \\
\text { Most partnered but } 2 \text { single mothers }\end{array}$ & $\begin{array}{l}22 \text { women had minor children } \\
8 \text { had pre-school children aged } \\
\text { from below } 1 \text { to } 5 \text { years } \\
\text { Most partnered but } 3 \text { single mothers }\end{array}$ \\
\hline
\end{tabular}

The interviews were semi-structured and covered themes relating to the women's experience of work during the crisis, work-life-balance, childcare, and household income. They also addressed the interviewees' views regarding gender roles, the employment situation of their partners', and their contributions to care and domestic work. The interviews were conducted in person, in their native language, and were digitally recorded, except for a small number of women who opted out. The interviews were transcribed and analyzed using a thematic template technique (King, 2004). The interview data were complemented with conversations with union officers in both countries about the changes in employment regulation, collective bargaining, employers' responses, and implications for the workers of the industries in question. Although the analysis below draws mainly on the interviews with the women, the meetings with trade union officers provided opportunities to contextualize and triangulate these data. 


\section{The experience of employment}

While the analysis of Eurostat LFS data above showed how low educated women in both countries faced increased difficulties in accessing and remaining in employment, the analysis here focuses on the actual experiences of women who actually did so. The key themes that emerged from the interviews were somewhat different in Portugal and Spain. The experience of Portuguese interviewees, characterized by low pay in a context of stability and continuity, contrasted with the accounts of insecurity and poor labor practices of the Spanish interviewees. In both cases these features preceded the crisis but were reinforced by it and further enabled by the labor market measures implemented in this period. In Portugal, low educated women working in manufacturing receive extremely low wages and during the crisis this was exacerbated by the freezing of the minimum wage and blockages in collective bargaining. Half of the interviewees were paid the national minimum wage which was, at the time of the interviews, €485 per month (or 692 in purchasing parity standards (PPS ${ }^{4}$ ) and the others were paid just a little above. All reported not having wage increases in the previous two years. They all worked full-time and the vast majority had permanent contracts and long tenures of at least ten years. Only three had entered the company in the previous two years and only two of them had been unemployed. These three women had fixed-term contracts but expected these to become permanent. The new regimes of working time flexibility were used in their workplaces but there was evidence of an effort to reconcile the firms' flexibility needs with the work-family reconciliation of workers who were mothers. In general, the Portuguese interviewees perceived their jobs to be secure but the low level of pay and the lack of wage increases was a major source of discontent.

In Spain, the interviewees were more heterogeneous in terms of the sectors where they worked. Their experiences reflected this greater diversity and were, in many ways, more negative. Even though they earned on average almost twice the wage of their Portuguese counterparts, their pay was also low by Spanish standards and typical of low skilled occupations. Eleven of the fifty three Spanish interviewees (twenty percent) were earning the minimum wage, €753/month (or 815 in PPS) in 2014. Of these, nine were part-timers who received an even lower monthly value based on the hours they worked. The contractual arrangements of the Spanish interviewees were also more diverse and more precarious than the Portuguese cohort with only twenty one women having permanent contracts, twelve in fixed-term contracts and the nineteen women in agro-food having a special type of seasonal contracts typical of the industry which is open-ended but not continuous. All the women in agro-food worked full-time but part-timers were found among textile, hospitality and care workers (twenty in total).

Three Spanish interviewees had entered employment from inactivity during the crisis in response to their husbands' unemployment but a quarter of the women interviewed in Spain also reported having been recently unemployed, in some cases more than once. In addition, half reported increases in working time, in most cases without a correspondent pay increase, six (fifteen percent) reported 
involuntary reductions in working time, twenty five (forty six percent) reported wage freezes, and eighteen (thirty three percent) had pay cuts. These adverse changes were experienced by women who worked in different sectors and had been imposed by their managers, who, as reported by some women told them that the employer could unilaterally modify working conditions by opting out from the collective agreements. Cases of firms dismissing workers during the crisis without this being justified by a visible decrease in output and in some cases without paying severance pay and other violations of employment rights were also widely witnessed by the Spanish women. Not surprisingly, there was a pervasive sense of job insecurity. The quote below summarizes many of the issues that were reported by the Spanish interviewees:

'We have to do the work of the employees who were fired but for a lower wage as we had several cuts in wages...but they don't pay us for overtime (...) We feel very insecure, we never know when they are going to call you and fire you, it is an awful situation.' (Spanish interviewee 46)

\section{The family economy}

The accounts of Portuguese and Spanish women were more similar in relation to the situation of their husbands and partners. A third of the women interviewed in Portugal and a quarter in Spain reported that their partners were or had been unemployed during the crisis. This was associated with a significant income loss. The unemployment benefit they received was, in general, fifty percent of previous earnings and some, having become long-term unemployed, no longer received it. Several other Spanish women reported that, like themselves, their husbands suffered significant pay cuts during the crisis. Similar cases reported in Portugal were mostly due to lower overtime work or pay. These experiences of unemployment and pay cuts or freezes of women or their husbands were associated with significant financial stress. 'Having to count every cent' in order to make ends meet was an expression used by several of the interviewees, who in both countries explained that their current household income was just enough for their regular expenses with food, rent or mortgage and bills but insufficient to cope with any extra or unexpected expense. Under these circumstances, women's employment and earnings had become crucial to cope with or avoid financial hardship of their families. As one woman in Portugal (interviewee 3) explained: 'If I didn't work, we would be in a crisis that was even deeper. This way we could deal with it, otherwise we wouldn't have been able to cope.'

In general, the women interviewed in both countries saw their wages as extremely important to the household budget. Their contributions had become fifty percent or above in a third of the cases; two women in each country had become the sole breadwinner following their husbands' unemployment. These changes, in turn, could affect family arrangements and childcare strategies and it is to this that we now turn. 


\section{Work-family reconciliation and childcare arrangements}

This study provides some insights of how women reconcile work with family life and how this may have changed during the crisis.

In Portugal despite the availability of nurseries, seven of the thirteen women with pre-school children had their children looked after by their mothers or mothers-in-law, one by her sister and only the remaining five used nurseries. While previous research indicated that family arrangements were preferred for children under three (Távora, 2012), a clear age pattern was not found here: there were cases of children who were seventeen months, two and three years in nurseries whereas those looked after by grandmothers' ranged from seven months to four and five years. All the women who used these family-based arrangements reported these to be their choice and that a nursery was available. Their justifications revolved around family-based solutions being more suited for younger children, children in nurseries catching diseases from each other and, prominently, the cost of nurseries. The nursery fees (reported to be seventy to eighty euros per child) were perceived as significant, particularly when considered against free childcare by grandmothers. For three of the mothers of older pre-school children (three to five years old) who did not attend nurseries, cost was a key reason for not having their child in a nursery. Portuguese interviewees did not report much involvement of husbands/partners in childcare except in evenings.

In Spain, the involvement of grandmothers was also substantial, but the childcare issues were rather different. The eight Spanish interviewees who had children below school age used nurseries except one woman who, being on a reduced schedule, shared with her unemployed husband the care of their two year old child. All the others used formal childcare. However, as most schools and nurseries finished at two or three pm, as is common in Southern Spain, there was a need for complementary arrangements. These varied among the twenty one women who had either school or pre-school children. Some (twelve) worked part-time whereas the others were aided by their own or partners' mothers. Despite the absence of grandmothers as the primary childcare arrangement in the Spanish study, they were still important complementary arrangements in these nine cases. Male partners were also involved but mostly those who were unemployed. While part-time work and reduced hours schemes seemed to help Spanish women to better manage the work-family interface, this involved lower pay. In turn, full-time working women faced increasing difficulties in balancing work with family due to longer and less predictable hours. This was particularly problematic for mothers but in general Spanish women struggled to combine full-time schedules with domestic work, which fell mostly on their shoulders.

\section{The domestic division of labor and gender-role attitudes}

Survey research has consistently shown that domestic division of labor and gender attitudes in Portugal and Spain are among the most traditional in Europe (Aboím, 2010; Moreno, 2013). The interviews explored whether the changes in women's employment situation and/or that of their male 
partners during the crisis were associated with changes in their gender values and roles. In line with previous research (Calzada and Brooks, 2013; Moreno and Marí-Klose, 2013), while the domestic division of labor was generally traditional in their homes, younger women, especially in Spain, reported a more egalitarian sharing of it. Yet their husbands' contributions were mostly to cooking and childcare and still described as 'help'. The latter is consistent with a traditional view of gender roles and an acceptance of domestic work as mainly a woman's responsibility. Still there were accounts of an increase of the participation in domestic work of unemployed husbands in both countries, although this was far from a reversal of roles or an equal sharing even in cases of women who worked full-time. In Spain, the contribution of unemployed husbands to childcare appeared particularly significant in the context of limited school and nursery hours. This was not observed in Portugal because there were no cases of unemployed partners of interviewees with young children.

In order to explore gender and work attitudes, the interviewees were asked to share their views about statements such as 'women should have their own income' (in Portugal) and 'having a job is the best way for women to be independent' (in Spain). The vast majority of women agreed with the statements despite a small number of women in each country (three to four) expressing the wish to look after their children at home but without having to depend on their husbands. There was a wide consensus on the importance of economic independence. Women emphasized how working and economic independence was important for their identity and self-esteem:

'A woman cannot be a woman without being economically independent.' (Spanish interviewee 2)

'I don't want to depend on my husband. No. I earn my money, my livelihood is provided by me. [...]I regret earning less than him, but I don't feel less of a person than he is. But I would if he provided for me. That would make me feel inferior.' (Portuguese interviewee 18)

The experience of employment and of a greater involvement of husbands in care and domestic work could be associated with a change of gender-role attitudes and work orientations. The three Spanish women who started working during the crisis appeared to realize then some of the benefits of employment and to somewhat change their traditional gender attitudes. The quote below summarizes some of these issues:

'I used to think that the family was more important for women than for men but since my husband became unemployed two years ago, he has been looking after our kid and doing the domestic work and I feel more fulfilled working.' (Spanish interviewee 16)

When asked to comment statements such as 'during economic crises, when few jobs are available men should have priority in the labor market', the vast majority disagreed. Their justifications were based on notions of egalitarianism and justice, emphasizing that women had the same need and/or the same right to work. The few women who agreed with the statement explained their position based on 
pre-existing inequalities, especially, in pay. The awareness of these inequalities also influenced their considerations even when they disagreed. The following quotes exemplify their reasoning:

'Men should not have priority but if their wage is higher, it is better that they are the ones getting to work.' (Spanish interviewee 47)

'No, I don't agree. Why men? Because they earn more than women? That's the only reason I can see.' (Portuguese interviewee 2)

'I agree because, I don't know why, but it's plain to see that men earn more money than women. I don't know why, because sometimes I think women in certain jobs are more efficient than men.' (Portuguese interviewee 24)

This raises issues about the interpretation of existing comparative survey data which tends to see the respondents' agreement with such statements as indicating traditional values. This study suggests that agreeing with prioritizing male access to jobs may instead reflect a pragmatic choice based on the awareness of existing gender pay inequalities.

In summary, the data in this subsection does not indicate significant change in gender attitudes. Evidence of relatively traditional attitudes to gender roles in the home coexisted with more modern and egalitarian views in both countries with regard to female employment, which was seen as a need and as a right of women. If anything, trends towards more modern views could be reinforced by the higher need for a female wage in the household and by some redistribution of roles in the family in cases of paternal unemployment, especially in Spain. Table 4 summarizes the key findings of this article, facilitating a comparison of the cases of Portugal and Spain. 
Table 4. The impact of recession and austerity on low educated women in Portugal and Spain

\begin{tabular}{|c|c|c|}
\hline & Portugal & Spain \\
\hline $\begin{array}{l}\text { Labour } \\
\text { market } \\
\text { participation }\end{array}$ & $\begin{array}{l}\text { Activity rates decreased. against } \\
\text { trend for women overall. } \\
\text { Employment rates decreased } \\
\text { markedly. } \\
\text { - Unemployment rates grew more } \\
\text { than for women overall. }\end{array}$ & $\begin{array}{l}\text { - } \quad \text { Activity rates increased. } \\
\text { - Unployment rates decreased. } \\
\text { dramatically overall, reaching } \\
\text { highest levels among low } \\
\text { educated women. }\end{array}$ \\
\hline $\begin{array}{l}\text { Impact of } \\
\text { labour } \\
\text { market } \\
\text { reforms }\end{array}$ & $\begin{array}{l}\text { - } \quad \text { Increased job insecurity. } \\
\text { - } \quad \text { of wer predictability and control } \\
\text { - } \quad \text { Real wage decline and greater } \\
\text { vulnerability to low pay. } \\
\text { - } \quad \text { Higher gender pay inequality. } \\
\text { - New equality rules in bargaining } \\
\text { may mitigate inequalities. }\end{array}$ & $\begin{array}{l}\text { Increased job insecurity and } \\
\text { precarity. } \\
\text { Lower predictability and control } \\
\text { of working hours. } \\
\text { - } \text { Real wage decline and greater } \\
\text { vulnerability to low and insecure } \\
\text { pay. } \\
\text { Higher gender pay inequality. }\end{array}$ \\
\hline $\begin{array}{l}\text { Impact of } \\
\text { welfare } \\
\text { reforms }\end{array}$ & $\begin{array}{l}\text { Expansion of childcare } \\
\text { maintained. } \\
\text { More egalitarian and generous } \\
\text { leave system from } 2009 . \\
\text { Elderly care programmes } \\
\text { maintained. }\end{array}$ & $\begin{array}{l}\text { Childcare or extension of } \\
\text { schedules stalled. } \\
\text { Withdrawal of regional support } \\
\text { for parental leave and no } \\
\text { extension of leave for fathers. } \\
\text { Elderly care programmes } \\
\text { reversed. }\end{array}$ \\
\hline $\begin{array}{l}\text { Experience of } \\
\text { women }\end{array}$ & $\begin{array}{l}\text { Key employment issues were } \\
\text { low pay and lack of increases. } \\
\text { Partners' unemployment and } \\
\text { lower/insecure income led to } \\
\text { financial stress but reinforced } \\
\text { women's employment } \\
\text { attachment. } \\
\text { Childcare services available but } \\
\text { use of grandmothers suggested } \\
\text { low affordability; unemployed } \\
\text { husbands involved in domestic } \\
\text { work. } \\
\text { Work critical to women's } \\
\text { identity; high value placed on } \\
\text { economic independence. }\end{array}$ & $\begin{array}{l}\text { - Key issues were employment } \\
\text { insecurity and precariety. } \\
\text { Employment and income } \\
\text { insecurity led to financial stress } \\
\text { but partners' unemployment } \\
\text { reinforced women's employment } \\
\text { attachment. } \\
\text { - Short childcare schedules require } \\
\text { additional arrangements and } \\
\text { limit mothers' working hours; } \\
\text { unemployed husbands involved } \\
\text { in childcare. } \\
\text { Work critical to women's } \\
\text { identity; high value placed on } \\
\text { economic independence. }\end{array}$ \\
\hline
\end{tabular}




\section{Discussion and conclusion}

The analysis in this article indicates a strong employment attachment of low educated women in both countries but also that they face particular risks of labor market exclusion. The labor market situation during the recession was a major barrier to low educated women's efforts to enter and/or remain in employment, particularly for the low educated. The labor market reforms had a negative impact on the conditions of employment, particularly in terms of job security, control over working time and earnings. Minimum wage freezes and the undermining of collective bargaining meant that many workers had their wages frozen or reduced. The interviews suggest that Spanish low educated women were particularly vulnerable to job and earnings insecurity and to undesired changes to their working times whereas their Portuguese counterparts increased their vulnerability to low pay.

The interviewees' discourse on the importance of employment for women's economic independence and linking it to notions of fairness and egalitarianism suggests that women's attachment to employment is increasingly strong even in Spain. In this country, women's employment position appears more constrained by unfavorable labor market circumstances than by traditional gender role attitudes. Unemployment has led to a (modest) increase of male partners' involvement in domestic work and, in the Spanish case, in childcare, although it is doubtful that this constitutes a long term shift - especially as the latter is likely to change with a move into employment. Women's attachment to employment has been reinforced by the growing importance of their income contributions to the household, which may prove a more lasting change in gender relations in the context of falling earnings and employment insecurity also for men but the recent labor market reforms created further barriers to women reaching secure segments of employment.

The evidence indicates a greater protection of policies that promote gender equality and support female employment and dual earner families in Portugal than in Spain where austerity destabilized the expansion of care services and improvements to leaves for parents. Still in Portugal the interview data suggests, even if tentatively due to the small number of cases, that in the crisis context of falling real earnings, the cost of formal childcare may have become less affordable for low educated women. In Spain, short childcare and school hours in the context of a more de-regulated labor market and, increasingly, long unpredictable hours, means that mothers' employment is more dependent on opportunities to work part-time in schedules that match childcare hours. Family assistance with childcare, especially from grandmothers continues to be widespread and necessary in both countries: in Spain (at least in some regions) due to the short nursery and school hours requiring complementary arrangements and in Portugal possibly due to affordability issues.

This study contributes to knowledge of how recession and austerity affect women and highlights the need for intersectional sensitivity (McBride et al., 2015), in this case with respect to the intersection between gender and socio-economic disadvantage. Firstly, it provides evidence of a greater impact of the labor market measures and welfare restraint on women with lower education 
qualifications, which were disproportionally affected by low pay and at least in the Spanish case, highly vulnerable to precariousness and income insecurity. Secondly, by drawing on evidence from two countries with different gender arrangements, it provides support to propositions that where dual earner patterns are not yet well-embedded in social norms, gender equality agendas and supportive policies are more threatened by recession and austerity than where women's position in employment and as co-breadwinners is well established, where these policies are more likely to be sustained (Rubery, 2014). Lastly, while research so far has tended to show a narrowing of gender differences during the recession due to the deterioration of employment conditions of both men and women, this study provides evidence from two countries that an increase of gender inequalities in employment are becoming visible, namely in the widening of the gender pay gap and women's over-representation among minimum wage earners. Overall, the study provides further evidence that gender-blind austerity coupled with the weakening of employment protection result in the widening of gender and social inequalities.

That leads us to the policy implications of this study. The continuing participation of low educated Portuguese women in employment may be partly dependent on a better affordability of childcare whereas in Spain women's opportunities and options would be most obviously improved by the extension of childcare hours along with regulations limiting excessive full-time and unpredictable hours. Addressing low pay and employment insecurity - and women's over-representation in it, is another pathway for reducing gender and social inequalities in employment in these countries. An important corollary here is that further progress towards equality cannot be achieved without an easing of austerity, as other authors have persuasively argued (Rubery, 2015), a re-regulation of the labor market and a reinstatement of wage setting institutions that protect the most vulnerable workers (ILO, 2012). In turn, the works by Prata (2017) and Lombardo (2017a), the first discussing the limited presence of gender equality concerns in the political process in Portugal and the second discussing the rise and increasing success of feminist contestation in Spain during the crisis, remind us of the importance of women political representation and activism for protecting and advancing women's and social rights.

In Portugal, there are some signs that a more positive economic outlook and a change of government by the end of 2015 after a successful completion of the adjustment program is leading to an easing of austerity, increases in the minimum wage and a more favorable environment to collective bargaining. This and the new equality rules on collective bargaining could possibly contribute to offset the negative effects of the crisis on low educated women workers and gender equality, though this may be an over-optimistic inference at this stage. In Spain, the post-crisis period has been marked by political instability, firstly due to the inconclusive results of two successive parliamentary elections, and secondly due to the upheaval in Catalonia, but the government's political orientation has not changed and so far there are little signs of a rethinking of austerity. 
1. The term 'low educated' used in this article corresponds to levels 0-2 of education attainment as defined by the International Standard Classification of Education (ISCED): less than primary, primary and lower secondary education.

2. The relatively high figures for Spain, however, obscure regional disparities, with coverage being higher in regions such as Madrid, Cataluña and the Basque country than in southern and central regions.

3. Eurostat Labour Force Survey regional series (Eurostat, 2017).

4. The PPS value computed by Eurostat includes two extra salaries legally due in June and December each year.

\section{References}

Aboim, S. (2010) Gender Cultures and the Division of Labour in Contemporary Europe. Sociological Review, 58,2, 171-96.

Addabbo, T., Rodríguez-Modroño, P. and Gálvez, L. (2015) Gender Differences in Labor Force Participation Rates in Spain and Italy under the Great Recession. Revista de Economía Mundial, 41, 21-42

Antonopoulos, R. (ed). (2014) Gender Perspectives and Gender Impacts of the Global Economic Crisis. New York: Routledge.

Baizán, P. (2009) Regional child care availability and fertility decisions in Spain. Demographic Research, 21, 803-842.

Bargawi, H., Cozzi, G. and Himmelweit, S. (2017) Economics and Austerity in Europe. Abingdon and New York: Routledge.

Bettio, F. and Verashchagina, A. (2014) Women and men in the 'Great European Recession'. In Karamessini, M. and Rubery, J. (ed.) Women and Austerity. The Economic Crisis and the Future for Gender Equality. London: Routledge, pp. 57-81.

Bettio, F., Corsi, M., D'Ippoliti, C., Lyberaki, A., Samek, M. and Verashchagina, A. (2013) The impact of the economic crisis on the situation of women and men and on gender equality policies. Luxembourg: Publications Office of the European Union.

Calzada, I. and Brooks, C. (2013) The Myth of Mediterranean Familism. European Societies, 15,4, 514-534.

Cruces, J., Álvarez, I., Trillo, F. and Leonardi, S. (2015) Impact of the euro crisis on wages and collective bargaining in southern Europe - a comparison of Italy, Portugal and Spain. In Van Gyes, G. and Schulten, T. (eds.) Wage bargaining under the new European Economic Governance. Alternative strategies for inclusive growth, Brussels: European Trade Union Institute, pp. 93-137.

Escobedo, A. and Wall, K. (2015) Leave policies in Southern Europe: continuities and changes. Community, Work \& Family, 18,2, 218-235. 
Escobedo, A., Meil, G. and Lapuerta, I. (2016) Spain. In Koslowski, A., Blum, S. and Moss, P. (ed.) 12th International Review of Leave Policies and Related Research 2016. International Network on Leave Policies and Research, pp. 325-39.

European Commission (2014) Key Data on Early Childhood Education and Care in Europe, 2014 ed. Eurydice and Eurostat Report. Luxembourg: Publications Office of the European Union.

Eurostat (2017) Online database. Available at: http://ec.europa.eu/eurostat/data/database [Accessed 13 April 2017]

Fernández-Rodríguez, C., Ibañez-Rojo, R. and Martínez-Lucio, M. (2016) Austerity and collective bargaining in Spain: The political and dysfunctional nature of neoliberal deregulation. European Journal of Industrial Relations 22(3): 267-280.

Ferreira, V. (2014) Employment and austerity: changing welfare and gender regimes in Portugal. In Karamessini, M. and Rubery, J. (ed.) Women and Austerity. The Economic Crisis and the Future for Gender Equality. London: Routledge, pp. 207-227.

Ferreira, V. and Monteiro, R. (2013) Trabalho, Igualdade e dialogo social. Lisboa: Comissão para a Igualdade no Trabalho e no Emprego.

Gabinete de Estratégia e Planeamento (2014) Carta Social: Rede de Serviços e Equipamentos. Lisboa: Gabinete de Estratégia e Planeamento, Ministério da Solidariedade, Emprego e Segurança Social.

Gálvez, L.; Rodríguez-Modroño, P. (2016). "A gender analysis of the Great Recession and austericide in Spain”. Revista Crítica de Ciências Sociais, 111, 133-152.

Gonzalez-Gago, E. and Segales, M. (2014) Women, gender equality and the economic crisis in Spain. In Karamessini, M. and Rubery, J. (ed.) Women and Austerity. The Economic Crisis and the Future for Gender Equality. London: Routledge, pp. 228-247.

Hook, J. (2015) Incorporating 'class' into work-family arrangements: Insights from and for Three Worlds. Journal of European Social Policy, 25,1, 14-31.

Ibáñez, Z. and León, M. (2014) Early Childhood Education and Care Provision in Spain. In León, M. (ed.) The Transformation of Care in European Societies, Palgrave MacMillan, pp 276-300.

ILO (2012) Global wage report 2012/2013. Geneva: International Labour Office.

INE (2017) Encuesta anual de estructura salarial. Serie 2008-2013. Available at: www.ine.es [Accessed 6 Nov 2017]

Instituto Nacional de Estatística (2016) Portal de Estatisticas Oficiais. Available at: www.ine.pt [Accessed 1 Oct 2016]

Kantola, J. and Lombardo, E. (eds.) (2017) Gender and the Economic Crisis in Europe: Politics, Institutions and Intersectionality. Palgrave MacMillan.

Karamessini, M. and Rubery, J. (2014) Economic Crisis and Austerity: Challenges to gender equality. In Karamessini, M. and Rubery, J. (ed.) Women and Austerity. The Economic Crisis and the Future for Gender Equality. London: Routledge, pp. 314-351. 
Keck, W. and Saraceno, C. (2013) The Impact of Different Social-Policy Frameworks on Social Inequalities among Women in the European Union: The Labour-Market Participation of Mothers. Social Politics, 20,3, 297-328.

King, N. (2004) Using templates in the thematic analysis of text. In Cassel, C. and Symon, G. (eds) Essential Guide to Qualitative Methods in Organizational Research. London: Sage, pp. 256270.

Korpi, W., Ferrarini, T. and Englund, S. (2013) Women's Opportunities under Different Family Policy Constellations: Gender, Class, and Inequality Tradeoffs in Western Countries Re-examined. Social Politics, 20,1, 1-40.

León, M. (2007) Speeding up or holding back?: Institutional factors in the development of childcare provision in Spain. European Societies, 9,3, 315-337.

León, M. and Pavolini, E. (2014) 'Social Investment' or Back to 'Familism': The Impact of the Economic Crisis on Family and Care Policies in Italy and Spain. South European Society and Politics, 19,3, 353-369.

Leschke, J. and Jepsen, M. (2014) Is the economic crisis challenging the prevailing gender regime? A comparison of Denmark, Germany, Slovakia and the United Kingdom. Social Politics, 21,4, 485-508.

Lombardo, E. (2017a) Austerity Politics and Feminist Struggles in Spain: Reconfiguring the Gender Regime? In Kantola, J. and Lombardo, E. (eds.) Gender and the Economic Crisis in Europe: Politics, Institutions and Intersectionality. Palgrave MacMillan, pp. 209-230.

Lombardo, E. (2017b) The Spanish Gender Regime in the EU Context: Changes and Struggles in Times of Austerity. Gender, Work and Organization, 24,1, 20-33.

Mandel, H. and Shalev, M. (2009) Gender, Class, and Varieties of Capitalism. Social Politics, 16,2, $161-181$.

McBride, A., Hebson, G. and Holgate, J. (2015) Intersectionality: are we taking enough notice in the field of work and employment relations?. Work, Employment and Society, 29,2, 331-41.

Moreno, A. (2013) The decline of the male breadwinner family model versus the persistence of gendered unpaid work in Spain. Families, Relationships and Societies, 2,3, 371-393.

Moreno, L. and Marí-Klose, P. (2013) Youth, family change and welfare arrangements. European Societies, 15,4, 493-513.

Muñoz-de-Bustillo, R. and Pinto Hernández, F. (2016) Reducing Precarious Work in Europe through Social Dialogue: the Case of Spain. Report for the European Commission, University of Salamanca.

Naldini, M. and Jurado, T. (2013) Family and welfare state reorientation in Spain and Inertia in Italy from a European perspective. Population Review, 52,1.

Pfau-Effinger, B. (1998) Gender cultures and the gender arrangement: A theoretical framework for cross-national gender research. Innovation, 11,2, 147-166. 
Prata, A. (2017) The visibility (and invisibility) of women and gender in parliamentary discourse during the Portuguese economic crisis (2008-2014). In Kantola, J. and Lombardo, E. (eds.) Gender and the Economic Crisis in Europe: Politics, Institutions and Intersectionality. Palgrave MacMillan, pp. 161-184

Rocha, F. (2014) Crisis and austerity policies in Spain: towards an authoritarian model of industrial relations. In Rocha, F. (ed.) The New EU Economic Governance and its impact on the National Collective Bargaining Systems. Madrid: Fundación 1º de Mayo, pp. 175-206.

Rocha, F. and Stoleroff, A. (2014) The challenges of the crisis and the external intervention in Portugal. In Rocha, F. (ed.) The New EU Economic Governance and its impact on the National Collective Bargaining Systems. Madrid: Fundación $1^{\circ}$ de Mayo, pp. 150-172.

Rodríguez-Modroño, P. and Matus, M. (2016) Políticas de cuidados a la infancia y mayores dependientes. Evolución y condicionamiento pro-mercado. Revista del CLAD Reforma y Democracia, 66, 99-130.

Rubery, J. (1988) Women and Recession. London: Routledge.

Rubery, J. (2014) From 'women and recession' to 'women and austerity': a framework for analysis. In Karamessini, M. and Rubery, J. (ed.) Women and Austerity. The Economic Crisis and the Future for Gender Equality. London: Routledge, pp. 17-36.

Rubery, J. (2015) Austerity, the Public Sector and the Threat to Gender Equality. The Economic and Social Review, 46,1, 1-27.

Távora, I. (2012) Understanding the high rates of employment among low-educated women in Portugal: A comparatively oriented case study. Gender, Work and Organization, 19,2, 93-118.

Távora, I. and Gonzalez, M. P. (2016) Labour market regulation and collective bargaining in Portugal during the crisis: Continuity and change. European Journal of Industrial Relations 22, 3, 251265 .

Visser, J. (2013) Wage Bargaining Institutions: From Crisis to Crisis. European Economy, Economic Papers, 488. Brussels: European Commission.

Walby, S. (2015) Crisis. Croydon: Polity Press. 